\title{
GAMBARAN PEMBERIAN ASI EKSKLUSIF TERHADAP KEJADIAN STUNTING PADA BALITA UMUR 24-60 BULAN DI KELURAHAN TANAH BARU BOGOR TAHUN 2018
}

\author{
Leila siti chairani ${ }^{1)},{\text { Merry maeta } \text { sari }^{2)} \text {, Andreanda nasution }}^{3)}$, Tika noor prastia ${ }^{4)}$
}

\author{
${ }^{1)}$ Kesehatan Ibu dan Anak, Program Studi Kesehatan Masyarakat, Fakultas Ilmu Kesehatan Universitas Ibn Khaldun \\ Bogor \\ Email : leilasitichairani@gmail.com \\ ${ }^{2)}$ Program Studi Kesehatan Masyarakat, Fakultas Ilmu Kesehatan Universitas Ibn Khaldun Bogor \\ Email : meta_ssi@yahoo.co.id \\ ${ }^{3)}$ Program Studi Kesehatan Masyarakat, Fakultas Ilmu Kesehatan Universitas Ibn Khaldun Bogor \\ Email : andre.anda@gmail.com \\ ${ }^{4)}$ Program Studi Kesehatan Masyarakat, Fakultas Ilmu Kesehatan Universitas Ibn Khaldun Bogor \\ Email : tikaprastia9@gmail.com
}

\begin{abstract}
Abstrak
Stunting merupakan kondisi kekurangan gizi secara kronis dimulai dari 1000 hari pertama kehidupan sehingga anak mengalami gangguan pertumbuhan dan perkembangan yang terlihat dari tinggi badan menurut umur di bawah batas normal. Stunting diakibatkan oleh asupan nutrisi yang tidak adekuat, praktek makan yang buruk dan seringnya terkena penyakit. Asupan nutrisi terbaik didapatkan dari pemberian ASI secara eksklusif. Tujuan penelitian ini adalah melihat gambaran karakteristik ibu dan balita, pemberian ASI eksklusif dan kejadian stunting pada balita umur 24-60 bulan di Kelurahan Tanah Baru Kota Bogor tahun 2018. Metode penelitian ini adalah studi deskriptif dengan teknik pengambilan data secara purposive sampling. Penelitian ini menggunakan uji univariat untuk melihat gambaran variabel. Hasil penelitian didapatkan ibu sebagian besar berada di sekitar umur 29 tahun, pendidikan terakhir ibu paling banyak adalah tamat SD sebesar $34,8 \%$, pekerjaan ibu paling banyak sebagai ibu rumah tangga sebanyak $92,4 \%$. Sebanyak 52,2\% balita berjenis kelamin perempuan dan sebagian besar berumur di sekitar usia 39 bulan. Didapatkan cakupan pemberian ASI eksklusif sebesar 31,5\% dan angka kejadian stunting sebesar 33,7\% yang berarti kejadian stunting di Kelurahan Tanah Baru sudah menjadi masalah kesehatan masyarakat.
\end{abstract}

\section{Kata kunci : Stunting, ASI Eksklusif, Balita.}

\section{PENDAHULUAN}

Kependekan merupakan salah satu bentuk malnutrisi yang merefleksikan kekurangan gizi yang terjadi secara kumulatif yang berlangsung lama atau dikenal dengan istilah kekurangan gizi kronis (hidden hunger). Anak dengan gizi kronis mengalami keterlambatan dalam pertumbuhan linier sehingga tidak tercapai pertumbuhan yang potensial. Anak tersebut tidak mencapai ratarata median pertumbuhan sesuai umur dan jenis kelamin (Lamid, 2015).

Dampak dari stunting berlangsung seumur hidup, artinya keadaan ini tidak dapat diperbaiki dan akan mengganggu perkembangan otak, lemahnya sistem imun, besarnya risiko terhadap penyakit diabetes 
dan kanker pada masa dewasa. Anak perempuan yang stunting akan tumbuh menjadi wanita yang kekurangan gizi, saat mengandung bayi tidak mendapat asupan gizi yang cukup dan keadaan ini akan terulang kembali (Thousand Days Organization, 2018).

WHO menguraikan penyebab kependekan secara langsung dan tidak langsung. Secara langsung, penyebab kependekan berkaitan dengan 4 faktor utama yaitu penyakit infeksi, praktik menyusui, ketersediaan makanan, serta lingkungan rumah tangga dan keluarga. Sementara secara tidak langsung, penyebab kependekan adalah faktor komunitas dan sosial yaitu ekonomi politik, kesehatan dan pelayanan kesehatan, pendidikan, sosial dan kebudayaan, pertanian dan sistem makanan, air, sanitasi dan lingkungan (Lamid, 2015).

Berdasarkan data Global Nutrition Report 2017, sebanyak 72 dari 140 negara di dunia masih menghadapi masalah stunting (WHO, 2017). Walaupun terjadi penurunan prevalensi anak pendek, tetapi belum mencapai target penurunan angka balita pendek yang ditetapkan (Global Nutrition Report, 2017).

Laporan Pemantauan Status Gizi tahun 2017 menunjukkan jumlah balita pendek (stunting) di Indonesia sebanyak 29,6\%. Menurut World Health Organization (WHO), prevalensi balita pendek menjadi masalah

\section{METODE}

Penelitian ini bertujuan mendeskripsikan variabel sehingga rancangan penelitian ini adalah penelitian deskriptif. Populasi pada penelitian ini adalah seluruh balita umur $24-60$ bulan di kelurahan Tanah Baru sebanyak 1186. Sampel pada penelitian ini adalah 92 balita umur 24-60 bulan di Kelurahan Tanah Baru. Bahan penelitian kesehatan masyarakat jika prevalensinya $20 \%$ atau lebih.

Cakupan ASI eksklusif yang ditargetkan di tahun 2017 oleh Program Direktorat Jenderal Bina Gizi dan KIA adalah $44 \%$. Namun, berdasarkan hasil Pemantauan Status Gizi tahun 2017 capaian ASI eksklusif hanya sebesar 35,7\%. Menurut Profil Kesehatan Jawa Barat, capaian ASI eksklusif tahun 2016 di Jawa Barat sebesar 46,4\%. Menurut Laporan Bulanan LB3, capaian pemberian ASI ekslusif tahun 2017 di Kota Bogor sebesar 49,5\% dan di Kelurahan Tanah Baru sebesar $27,1 \%$.

Menurut Profil Kesehatan Jawa Barat, pada tahun 2016 jumlah stunting di Jawa Barat sebesar 35,3\%. Prevalensi yang tertinggi di Kabupaten Bandung Barat $(52,5 \%)$ dan terendah di Kota Depok $(25,7 \%)$. Menurut laporan Bulan Penimbangan Balita kejadian stunting tahun 2017 di Kota Bogor sebesar 3,29\% (5.538 balita), di Bogor Utara sebesar 9,4\% (1.387 balita), dan angka tertinggi di Kota Bogor berada di Kelurahan Tanah Baru dengan angka 10,5\% (414 balita). Berdasarkan hal tersebut di atas maka perlu dilakukan penelitian tentang gambaran pemberian ASI ekslusif terhadap kejadian stunting di Kelurahan Tanah Baru tahun 2018.

Penelitian ini bertujuan mengetahui gambaran karakteristik ibu dan balita, pemberian ASI eksklusif dan kejadian stunting pada balita umur 24-60 bulan di Kelurahan Tanah Baru Bogor tahun 2018.

adalah data primer. Data primer yaitu data yang dikumpulkan secara langsung dari responden yaitu data pemberian ASI eksklusif dan kejadian stunting pada balita umur 24-60 bulan. Untuk mengumpulkan variabel karakteristik ibu dan balita serta pemberian ASI eksklusif diukur dengan kuesioner dan untuk mengukur variabel kejadian stunting, 
tinggi badan balita diukur dengan microtoise. Sampel diambil secara purposive sampling, dengan kriteria inklusi yang terdiri dari balita umur 24-60 bulan, balita mempunyai ibu kandung, ibu dan balita bersedia menjadi responden dan tidak mengalami gangguan mental. Untuk mengetahui gambaran karakteristik ibu dan balita, pemberian ASI eksklusif dan kejadian stunting dilakukan analisis univariat dan hasilnya dalam bentuk distribusi frekuensi. Untuk variabel numerik dalam bentuk nilai rerata dan untuk variabel kategorik dalam bentuk nilai frekuensi/proporsi.

\section{HASIL}

Tabel 1. Distribusi Frekuensi Karakteristik Ibu terdiri dari Umur, Pendidikan dan Pekerjaan di Kelurahan Tanah Baru Tahun 2018

\begin{tabular}{lll}
\hline Karakteristik Ibu & \multicolumn{2}{c}{ Hasil Analisis Univariat } \\
\hline Umur & Median & 29 Tahun \\
& Minimum & 19 Tahun \\
& Maksimum & 45 Tahun \\
& & \\
\hline Pendidikan Terakhir & Tidak tamat SD & $5(5,4 \%)$ \\
& SD & $32(34,8 \%)$ \\
& SMP & $25(27,2 \%)$ \\
& SMA/SMK & $25(27,2 \%)$ \\
& Perguruan Tinggi & $5(5,4 \%)$ \\
& & \\
\hline Pekerjaan & Ibu rumah tangga & $85(92,4 \%)$ \\
& Buruh & $2(2,2 \%)$ \\
& Pegawai swasta & $3(3,3 \%)$ \\
& & \\
\hline
\end{tabular}

Dari hasil penelitian didapatkan, sebagian besar ibu berada di sekitar umur 29 tahun, 34,8\% ibu berpendidikan terakhir SD dan $92,4 \%$ ibu tidak bekerja atau sebagai ibu rumah tangga. 
Tabel 2. Distribusi Frekuensi Karakteristik Balita Umur 24-60 Bulan (Umur dan Jenis Kelamin) di Kelurahan Tanah Baru Tahun 2018

\begin{tabular}{llll}
\hline \multicolumn{3}{l}{ Karakteristik Anak (Hasil Analisis } & Univariat) \\
\hline Umur & Median & 39 & bulan \\
\hline & Minimum & 24 & bulan \\
\hline & Maksimum & 59 & bulan \\
& & \\
\hline Jenis Kelamin & Laki-Laki & $44(47,8 \%)$ \\
\hline & Perempuan & $48(52,2 \%)$ \\
& & \\
\hline
\end{tabular}

Dari hasil penelitian didapatkan, perempuan dan sebagian besar berumur di sebanyak $52,2 \%$ balita berjenis kelamin sekitar usia 39 bulan.

Tabel 3. Distribusi Frekuensi Gambaran Pemberian ASI Ekslusif pada Balita Umur 24-60 Bulan di Kelurahan Tanah Baru Tahun 2018

\begin{tabular}{lll}
\hline Pemberian ASI Eksklusif & Frekuensi & Persentase \\
\hline ASI Eksklusif & 29 & $31,5 \%$ \\
Tidak ASI Eksklusif & 63 & $68,5 \%$ \\
\hline Total & 92 & $100 \%$ \\
\hline
\end{tabular}

Dari hasil penelitian didapatkan, Kelurahan Tanah Baru tahun 2018 tidak sebanyak $68,5 \%$ balita umur $24-60$ bulan di mendapatkan ASI ekslusif .

Tabel 5.4 Distribusi Frekuensi Gambaran Kejadian Stunting pada Balita Umur 24-60 Bulan di Kelurahan Tanah Baru Tahun 2018

\begin{tabular}{lll}
\hline Kejadian Stunting & Frekuensi & Persentase \\
\hline Stunting & 31 & $33,7 \%$ \\
Tidak Stunting & 61 & $66,3 \%$ \\
\hline Total & 92 & $100 \%$ \\
\hline
\end{tabular}

Dari hasil penelitian didapatkan, sebanyak 33,7\% balita umur 24-60 bulan di Kelurahan Tanah Baru tahun 2018 mengalami stunting yang berarti sudah menjadi masalah kesehatan masyarakat (>20\%). 


\section{PEMBAHASAN}

\section{Karakteristik Ibu}

Hasil penelitian menunjukkan ibu yang berusia < 20 tahun memiliki anak yang stunting. Dalam konsep penyebab kependekan menurut WHO tahun 2013, salah satu penyebab langsung terhadap kependekan adalah faktor ibu yaitu kehamilan remaja. Kehamilan di bawah umur memuat risiko yang besar. (http://dp2m.umm.ac.id).

Hamil remaja juga bisa mengakibatkan persalinan prematur dan berat badan lahir rendah (BBLR). Berat badan lahir rendah (BBLR) juga dipengaruhi gizi saat hamil kurang dan juga umur ibu yang belum menginjak 20 tahun. BBLR sebagai prediktor kuat pertumbuhan selanjutnya, sehingga jika tidak tertanggulangi juga akan mengakibatkan stunting.

Berdasarkan hasil penelitian, ditemukan 6 dari 20 ibu yang usianya $<20$ dan $>35$ tahun masih bisa memberikan ASI eksklusif. Hal ini sejalan dengan penelitian Isroni Astuti tentang determinan pemberian ASI eksklusif pada ibu menyusui tahun 2013 menunjukkan tidak ada hubungan yang signifikan antara umur ibu dengan pemberian ASI Eksklusif.

Hasil penelitian menunjukkan 77,4\% anak stunting memiliki ibu yang berpendidikan rendah $(\leq \mathrm{SMP})$. Tingkat pendidikan orang tua sangat mempengaruhi pertumbuhan anak balita. Tingkat pendidikan akan mempengaruhi konsumsi pangan melalui cara pemilihan bahan pangan (Hidayat, 1989 dalam Suyadi, 2009).

Rendahnya pendidikan orangtua khususnya ibu, merupakan faktor penyebab penting terjadinya KEP. Hal ini karena adanya kaitan antara peran ibu mengasuh anaknya. Berdasarkan penelitian Venny dkk tentang faktor-faktor yang berhubungan dengan kejadian stunting pada balita usia 2459 bulan di Desa Wawatu Kecamatan
Moramo Utara Kabupaten Konawe Selatan tahun 2017 menunjukkan bahwa adanya hubungan antara pola asuh Ibu dengan kejadian stunting pada balita usia 24-59 bulan di Desa Wawatu Kecamatan Moramo Utara Kabupaten Konawe Selatan Tahun 2017.

Berdasarkan penelitian Farah dkk tentang faktor-faktor yang mempengaruhi kejadian stunting pada anak balita di wilayah pedesaan dan perkotaan tahun 2015 menunjukkan adanya hubungan antara variabel pendidikan ibu, pendapatan keluarga dan pengetahuan ibu mengenai gizi terhadap kejadian stunting pada anak balita antara di desa dan kota.

Hasil penelitian menunjukkan 93,5\% anak stunting memiliki ibu yang tidak bekerja (ibu rumah tangga). Walaupun ibu memiliki banyak waktu untuk mengasuh anaknya, tetapi rendahnya pendidikan ibu menyebabkan kurangnya pemahaman tentang cara mencapai pertumbuhan dan perkembangan anak yang optimal. Masyarakat dengan tingkat pendidikan yang rendah akan lebih baik mempertahankan tradisi-tradisi yang berhubungan denga makanan, sehingga sulit menerima informasi baru bidang gizi (Soehardjo, 1989).

\section{Karakteristik Balita}

Berdasarkan hasil penelitian, kejadian stunting pada balita umur 24-60 bulan di kelurahan Tanah Baru sebesar 33,7\%. Bila stunting dikategorikan pada balita pendek dan sangat pendek, maka $67,7 \%$ balita dikategorikan pendek dan 32,2\% dikategorikan sangat pendek. Bila kejadian stunting ditinjau menurut jenis kelamin, pada balita laki-laki sebesar $61,3 \%$ dan anak perempuan sebesar $38,7 \%$. Bila kejadian stunting ditinjau menurut umur, terjadi pada balita umur 2 tahun sebanyak $41,9 \%$, umur 3 
tahun sebanyak $25,8 \%$ dan umur 4 tahun sebanyak $32,2 \%$.

\section{ASI Eksklusif}

Berdasarkan hasil penelitian, hanya $31,5 \%$ balita umur $(24-60)$ bulan yang mendapat ASI eksklusif di kelurahan Tanah Baru mencapai 31,5\%. Angka ini belum mencapai target dari Program Direktorat Jenderal Bina Gizi dan KIA pada tahun 2017 sebesar $44 \%$. Terdapat $68,5 \%$ balita usia $24-$ 60 bulan tidak mendapatkan ASI eksklusif, dengan alasan ASI sedikit/tidak ada sama sekali yaitu sebanyak 35,9\%, puting ibu lecet yaitu sebanyak 2,2\%, ibu bekerja yaitu sebanyak 2,2\%, dan alasan lain-lain seperti diberikan susu formula saat lahir secara caesar, anak rewel, ibu khawatir anak kurus, kebiasaan sebanyak 28,3\%. Alasan tersebut bukan menjadi penghambat ibu untuk memberikan ASI secara eksklusif, karena menurut teori hanya ada 3 kendala yang diperbolehkan ibu tidak memberikan ASI secara eksklusif, yaitu ibu terkena HIV, TBC aktif dan Hepatitis B aktif, puting masuk dan bayi dirawat sehingga terpisah dalam jangka waktu yang lama (Maryunani, 2012).

Pada penelitian ini ditemukan $45,7 \%$ balita usia usia 24-60 bulan diberikan susu formula sebelum balita berumur 6 bulan. Balita yang diberikan susu formula sejak lahir sebanyak $21,7 \%$, sampai 1 bulan sebesar $10,9 \%$, sampai 2 bulan sebesar $6,5 \%$, sampai 3 bulan sebesar $14,1 \%$, sampai 4 bulan sebesar 2,2\%, sampai 5 bulan sebesar 13,0\%.

Dari hasil penelitian, balita juga diberikan makanan atau minuman sebelum berumur 6 bulan, 15,2\% balita diberikan air putih dan biskuit, $14,1 \%$ balita diberikan madu, $12,0 \%$ balita diberikan bubur dan sebanyak dan 3,3\% balita diberikan buah.

Balita yang diberikan makanan atau minuman sebelum umur 6 bulan akan meningkatkan risiko kekurangan gizi, meningkatkan risiko terkena penyakit, sistem pencernaannya belum siap menerima MPASI, meningkatkan risiko alergi terhadap makanan, meningkatkan risiko obesitas (Maryunani, 2012).

Berdasarkan penelitian Farah dkk tentang faktor-faktor yang mempengaruhi kejadian stunting pada anak balita di wilayah pedesaan dan perkotaan tahun 2015 diketahui bahwa pemberian ASI eksklusif dan umur pertama pemberian MP-ASI merupakan faktor yang memberikan hubungan antara pola asuh dengan kejadian stunting pada anak balita yang baik yang berada di wilayah pedesaan maupun perkotaan. Anak balita yang diberikan ASI eksklusif dan MP-ASI sesuai dengan dengan kebutuhannya dapat mengurangi resiko tejadinya stunting. Hal ini karena pada usia 0-6 bulan ibu balita yang memberikan ASI eksklusif yang dapat membentuk imunitas atau kekebalan tubuh anak balita sehingga dapat terhindar dari penyakit infeksi. Setelah itu pada usia 6 bulan anak balita diberikan MP-ASI dalam jumlah dan frekuensi yang cukup sehingga anak balita terpenuhi kebutuhan zat gizinya yang dapat mengurangi risiko terjadinya stunting (Aridiyah dkk, 2015).

\section{Stunting}

Stunting merupakan masalah gizi yang sifatnya kronis sebagai akibat dari keadaan yang berlangsung lama, seperti masalah kemiskinan, perilaku hidup tidak sehat, dan pola asuh/pemberian makan yang kurang baik dari sejak anak dilahirkan yang mengakibatkan anak menjadi pendek. Menurut World Health Organization (WHO), prevalensi balita pendek menjadi masalah kesehatan masyarakat jika prevalensinya $20 \%$ atau lebih sehingga kejadian stunting pada balita umur 24-60 bulan di Kelurahan Tanah dari hasil penelitian ini sudah menunjukkan masalah kesehatan masyarakat. 


\section{Sebaran Balita Menurut Pemberian ASI Ekslusif dan Kejadian Stunting}

Berdasarkan hasil penelitian menunjukkan bahwa balita yang diberikan ASI eksklusif lebih banyak tumbuh menjadi balita yang normal daripada tumbuh menjadi balita stunting. Hal ini memperlihatkan ASI eksklusif membantu balita dalam mencapai standar pertumbuhan dan perkembangannya. Hal ini sejalan dengan penelitian yang dilakukan oleh Sri Indrawati tentang hubungan pemberian ASI eksklusif dengan kejadian stunting pada anak usia 2-3 tahun di Desa Karangrejek Wonosari Gunungkidul tahun 2016, ternyata terdapat hubungan yang signifikan antara pemberian ASI eksklusif dengan kejadian stunting. ASI merupakan asupan gizi yang sesuai dengan dengan kebutuhan akan membantu pertumbuhan dan perkembangan anak. Bayi yang tidak mendapatkan ASI dengan cukup berarti memiliki asupan gizi yang kurang baik dan dapat menyebabkan kekurangan gizi salah salah satunya dapat menyebabkan stunting (Indrawati, 2016).

\section{KESIMPULAN}

Pada balita umur 24-60 bulan di Kelurahan Tanah Baru tahun 2018 ditemukan sebagian besar berumur 39 bulan dan sebagian besar balita adalah perempuan. Ibu dari balita rerata berumur 29 tahun, tamat SD dan ibu tidak bekerja atau ibu rumah tangga. Cakupan pemberian ASI eksklusif sebesar $31,5 \%$ balita yang mendapatkan ASI eksklusif dan angka tersebut belum mencapai target
Namun, pada tabel silang di atas juga menunjukkan bahwa hanya $31,7 \%$ balita yang tidak mendapatkan ASI eksklusif yang stunting. Hal ini sejalan dengan penelitian yang dilakukan Marlan Pangkong dkk, tentang hubungan antara pemberian ASI eksklusif dengan kejadian stunting pada anak usia 13-36 bulan di Wilayah Kerja Puskesmas Sonder, bahwa tidak ada hubungan yang signifikan antara pemberian ASI eksklusif dengan kejadian stunting. Berdasarkan penelitian Bertalina \& Amelia tentang hubungan asupan gizi, pemberian ASI eksklusif, dan pengetahuan ibu dengan status gizi (TB/U) balita 6-59 bulan tahun 2018 menunjukkan bahwa tidak ada hubungan yang bermakna antara pemberian ASI eksklusif dengan status gizi balita/stunting.

Menurut teori bahwa ASI Eksklusif bukan merupakan satu-satunya faktor yang mempengaruhi kejadian stunting terdapat faktor lain seperti asupan gizi, penyakit infeksi, ketersediaan pangan, status gizi ibu hamil, berat badan lahir, panjang badan lahir dan MPASI (Kemenkes RI, 2012).

cakupan pemberian ASI eksklusif tahun 2017 di Indonesia sebesar 44\% dan angka kejadian stunting sebesar 33,7\% yang berarti kejadian stunting di Kelurahan Tanah Baru sudah menjadi masalah kesehatan masyarakat. Disarankan balita untuk mengukur tinggi badan secara rutin dengan cara pengukuran yang benar. 


\section{DAFTAR PUSTAKA}

[1] Aridiyah, Rohmawati dan Ririanty. (2015). Faktor-faktor yang Mempengaruhi Kejadian Stunting pada Anak Balita di Wilayah Pedesaan dan Perkotaan. e-Jurnal Pustaka Kesehatan, vol. 3 (no. 1)

[2] Astuti, Isroni. (2013). Determinan Pemberian ASI Eksklusif Pada Ibu Menyusui. Jurnal Health Quality Vol. 4 No. 1, Nopember 2013, Hal. 1 - 76

[3] Bachtiar, A., Achmad, E.K., \& Hartriyanti, Y. (2000). Metodologi Penelitian Kesehatan. Jakarta : FKMUI.

[4] Bahaya Kehamilan di Bawah Umur. Oktober 7, 2018. http://dp2m.umm.ac.id/files/file/INFOR MASI\%20PROGRAM\%20INSENTIF \%20RISTEK/7\%20BAHAYA\%20KEH AMILAN\%20DI\%20BAWAH\%20UM $\underline{\text { UR.pdf }}$

[5] Bakti Husada. (2015). Rencana Strategis Program Direktorat Jenderal Bina Gizi dan KIA Tahun 2015-2019. Jakarta : Bakti Husada.

[6] Bertalina dan Amelia. Hubungan Asupan Gizi, Pemberian ASI Eksklusif, dan Pengetahuan Ibu dengan Status Gizi (TB/U) Balita 6-59 Bulan. Jurnal Kesehatan Volume 9, Nomor 1, April 2018 ISSN 2086-7751 (Print), ISSN 2548-5695 (Online) http://ejurnal.poltekkestjk.ac.id/index.php/JK

[7] Dahlan, M.S. (2016). Langkah-Langkah Membuat Proposal Penelitian Bidang Kedokteran dan Kesehatan Seri 3 Edisi 2. Jakarta : CV Sagung Seto.

[8] Dahlan, M.S. (2013). Statistik untuk Kedokteran dan Kesehatan Edisi 5. Jakarta : Salemba Medika.

[9] Dalimunthe, S.M. (2015). Gambaran Faktor-Faktor yang Kejadian Stunting Pada Balita Usia 24-59 Bulan di
Provinsi Nusa Tenggara Barat Tahun 2010 (Analisis Data Sekunder Riskesdas 2010) (Skripsi). Jakarta: Universitas Islam Negeri Syarif Hidayatullah

[10] Development Initiatives, 2017. Global Nutrition Report 2017: Nourishing the SDGs. Bristol, UK: Development Initiatives

[11] Dinas Kesehatan Jawa Barat. (2017). Profil Kesehatan Provinsi Jawa Barat Tahun 2016. Bandung : Dinkes Provinsi Jawa Barat

[12] Dinas Kesehatan Kota Bogor. (2018). Laporan Bulanan LB3. Bogor : Dinkes Kota Bogor.

[13] Direktorat Bina Gizi. (2011). Keputusan Menteri Kesehatan Republik Indonesia Nomor 1995/MENKES/SK/XII/2010 Tentang Standar Antropometri Penilaian Status Gizi. Jakarta : Kementrian Kesehatan.

[14] Hastono, S.P. (2016). Analisis Data pada Bidang Kesehatan. Depok : PT Rajagrafindo Persada

[15] Indrawati, S. (2016). Hubungan Pemberian ASI Eksklusif Dengan Kejadian Stunting Pada Anak Usia 2-3 Tahun Di Desa Karangrejek Wonosari Gunungkidul (Skripsi). Yogyakarta: Universitas 'Aisyiyah

[16] Infodatin. (2016). Situasi Balita Pendek. Jakarta : Pusat Data dan Informasi Kemenkes RI.

[17] Kementrian Kesehatan. (2015). Rencana Strategis Kementrian Kesehatan Tahun 2015-2019. Jakarta: Author

[18] Kementrian Kesehatan. (2018). Buku Saku Pemantauan Status Gizi Tahun 2017. Jakarta : Kemenkes.

[19] Kullu, Yasnani dan Lestari. (2017). Faktor-Faktor Yang Berhubungan 
Dengan Kejadian Stunting Pada Balita Usia 24-59 Bulan Di Desa Wawatu Kecamatan Moramo Utara Kabupaten Konawe Selatan Tahun 2017. Jurnal Ilmiah Mahasiswa Kesehatan Masyarakat Vol. 3/No.2/ April 2018; Issn 2502-731x ,

[20] Lamid, Astuti. (2015). Masalah Kependekan (Stunting) pada Anak Balita : Analisis Prospek Penanggulangannya di Indonesia. Bogor : PT Penerbit IPB Press.

[21] Lestari, Zuraida dan Larasati. (2013). Hubungan Tingkat Pengetahuan Ibu tentang Air Susu Ibu dan Pekerjaan Ibu dengan Pemberian ASI Eksklusif di Kelurahan Fajar Bulan. Medical Journal of Lampung University Volume 2 No 4

[22] Maryunani, Anik. (2012). Inisiasi Menyusui Dini, ASI Eksklusif dan Manajemen Laktasi. Jakarta : CV. Trans Info Media.

[23] Novita, Gurnida dan Garna. (2008). Perbandingan Fungsi Kognitif Bayi Usia 6 Bulan yang Mendapat dan yang Tidak Mendapat ASI Eksklusif. Sari Pediatri, Vol. 9, No. 6

[24] Pangkong, M., Rattu, A.J.M., \& Malonda N.S.H. Hubungan antara Pemberian ASI Eksklusif dengan
Kejadian Stunting pada Anak Usia 1336 Bulan di Wilayah Kerja Puskesmas Sonder. Manado: Universitas Sam Ratulangi

[25] Sinaga, D.C. (2012). Gambaran Tingkat Pengetahuan tentang Hipertensi pada Masyarakat yang Merokok di RW 01 Kelurahan Pondok Cina, Beji, Depok (Skripsi). Depok: Universitas Indonesia

[26] Siregar, M.A., (2004). Pemberian ASI Eksklusif dan Faktor-Faktor yang Mempengaruhinya. Sumatera Utara : Universitas Sumatera Utara

[27] Sugiyono. (2014). Metode Penelitian Pendidikan Pendekatan Kuantitatif, Kualitatif, dan R\&D. Bandung: Alfabeta.

[28] Supariasa, I.D.N., Bakri, B., \& Fajar, I. (2002). Penilaian Status Gizi. Jakarta : EGC.

[29] Thousand Days . (2018). Stunting. Washington, DC : Author

[30] Tinjauan Pustaka. Oktober 7, 2018. http://repository.unimus.ac.id/1035/3/12 $\% 20 \mathrm{BAB} \% 20 \mathrm{II} . \mathrm{pdf}$

[31] Williams, L., \& Wilkins. (2007). Ilmu Gizi Menjadi Sangat Mudah, Ed.2 (dr.Linda Dwijayanthi, Penerjemah.). Jakarta: EGC. 